\title{
THE EFFECT OF ONOMATOPOEIA IN COMIC STRIPS AND INSTRUMENTAL MOTIVATION TOWARDS STUDENTS' READING COMPREHENSION ACHIEVEMENT
}

\author{
Aulia Putri $^{1}$; Yuli Angraini ${ }^{2}$; Sulastri Manurung ${ }^{3}$ \\ English Education Study Program, University of Riau Kepulauan, \\ Batam, Indonesia \\ auliaputri1983@yahoo.com ${ }^{1}$; angraini_yuli@yahoo.com ${ }^{2}$;astri.manru@yahoo.com ${ }^{3}$
}

\begin{abstract}
The aims of the research were to measure a significant effect on students' average scores of reading comprehension achievement between students:1)who both had high instrumental motivation in experiment class (Onomatopoeia in Comic Strips) and control class;2) who had high instrumental motivation in control class and the ones who had middle instrumental motivation in experiment class;3) who both had middle instrumental motivation in experiment class (Onomatopoeia in Comic Strips) and control class;4) who had high instrumental motivation in experiment class and the ones who had middle instrumental motivation in control class; and 5) to find whether there was an interaction or not on students' reading comprehension achievement taught using Onomatopoeia in Comic Strips towards instrumental motivation. Experimental with factorial design was used in this research by using 40 samples of the third semester students of English Education Study Program of UNRIKA classified into high and middle instrumental motivation. The validity used content validity while reliability of the data measured by Cronbach Alpha using SPSS 24. The data were collected through Onomatopoeia test and Gardner's instrumental motivation questionnaire. It was found from the analysis that both of the data were normal, homogenous and all hyphoteses had a significant effect.
\end{abstract}

Keywords: Onomatopoeia in Comic Strips, Instrumental Motivation, Reading

\section{INTRODUCTION}

Reading is a great subject, however, too much spending time in a common long reading texts can lead into disasters not only for lecturers but also for students. Most of all academic reading offered the official form of rigid curriculum by ignoring students' need and the lecturers' mood though it is unavoidable that students must read something to make a better understanding. However, the process of that could turn into a nightmare everytime they came into the class and lengthen their desperation if they had no strategy at all to cope with that. There were thousand of reading strategies offered to them whether through internet, bookstores or universities, however still in students' mind gathered bunches of thought. Started from the first thought when they saw the first page of the book then continued to see at a glance those very tiny words inside the thick book they must read, if they had to read that book then their eyes would be blurred after 5 minutes then they would travel in their own 
dream. When they awoke all they remembered that they already ran out of time to finish their reading tasks.

The second thought was the time. If students had a job plus they had to babysit their nephew or their own children, the time often haunted their mind. They already made complicated relationship with their personal life, as students and also as workers. On the other hand, teaching reading for some educators is kind of a challenge. They already made plans to teach with great scheme of their lesson plan and fabulous exercises exactly what the curriculum asked them, but in the application, they were failed. Students just saw their explanation but their mind was busy making affairs with their own other life. Those factors could vanish their inner motivation while motivation itself could help them to reduce their mind pressure.

To order students to read is not so hard but to get their comprehension about the subject will take educators' patience higher. When talking about comprehension, it means students do not just read like that, but they need to understand what it is written in that text they read. As in some cases, for example, people faced complicated situation, something that was out of their capacity to understand the situation. In crime scene investigation, it had no obstacles to solve the mystery for policemen or detective who got used to with that job, but it would be an extraordinary action if common people could track the crime based on what they usually watched or the way they read to connect the mystery to find the answers.

Another case as a sample when someone saw the weird car which passed by then suddenly there was shocking shout which asked for help then automatically his or her memory would be reminded of the car's number or any visual clues that dropped in his or her mind that time as the event was so fast. This is what Beale (2008:29) called building bridges of knowledge. When people read about something new, they relate it to some of their existing background knowledge and stick the two together.

Those concepts stimulated the idea about Onomatopoeia in Comic Strips as a strategy in teaching reading. Students should use their analytical thinking side by observing and identifying the words that have connection with the sound they hear in real life in reading text in the form of comic strips. In other words, their scope of perspective could be extended as their mind was trained automatically to to think faster everytime they read any texts.

\section{Visual Language}

Visual language is the use of visual images to communicate ideas, which are the representation of an illustrator's concepts. Illustrators convey ideas and messages and solve problems through distinct and personal visual languages. The emotions, feelings and behavior 
of the viewer are manipulated through numerous creative possibilities and the use of symbolism, exaggeration, visual metaphors, similes and juxtaposition. Developing a personal visual language involves incessant practice, research and an acute awareness of context and the target audience (Wigan, 2009:257).

\section{Language Types}

Kent (2011) mentioned there were two language types:

\section{Literal Language}

It is language that means exactly what is said.

For Example: Sit down!

Literally meaning: "sit down" as in: "sit in your seat now, please."

\section{Figurative Language}

Whenever people describe something by comparing it with something else, they are using figurative language. To be figurative is to not mean what people say but imply something else.

For Example: Let's chill! (It did not mean the speaker was suggesting the listener got into freezer)

\section{Onomatopoeia}

Onomatopoeia is the use or creation of words imitating the sounds to which they refer: for example, buzz, swoosh, drip, bang (Danesi, 2009:218). Abrams et al. (2009:251) said that sometimes onomatopoeia called echoism, is used both in a narrow and in a broad sense. In the narrow and most comon use, onomatopoeia designates a word, or a combination of words, whose sound seem to resemble closely the sound it denotes: "hizz", "buzz", "rattle", "bang." There is no exact duplication, however, of nonverbal by verbal sounds; the perceived similarity is due as much to the meaning, and to the sensation of articulating the words, as to their sounds. In the broad sense, "onomatopoeia" is applied to words or passages which seem to correspond to, or to strongly suggest, what they denote in any waywhatever - in size, movement, tactile feel, duration, or force, as well as sound.

There were two types of Onomatopoeia used in this research. They were Onomatopoeia in Comic Strips and in Poem. 
Onomatopoeia in Comic Strips
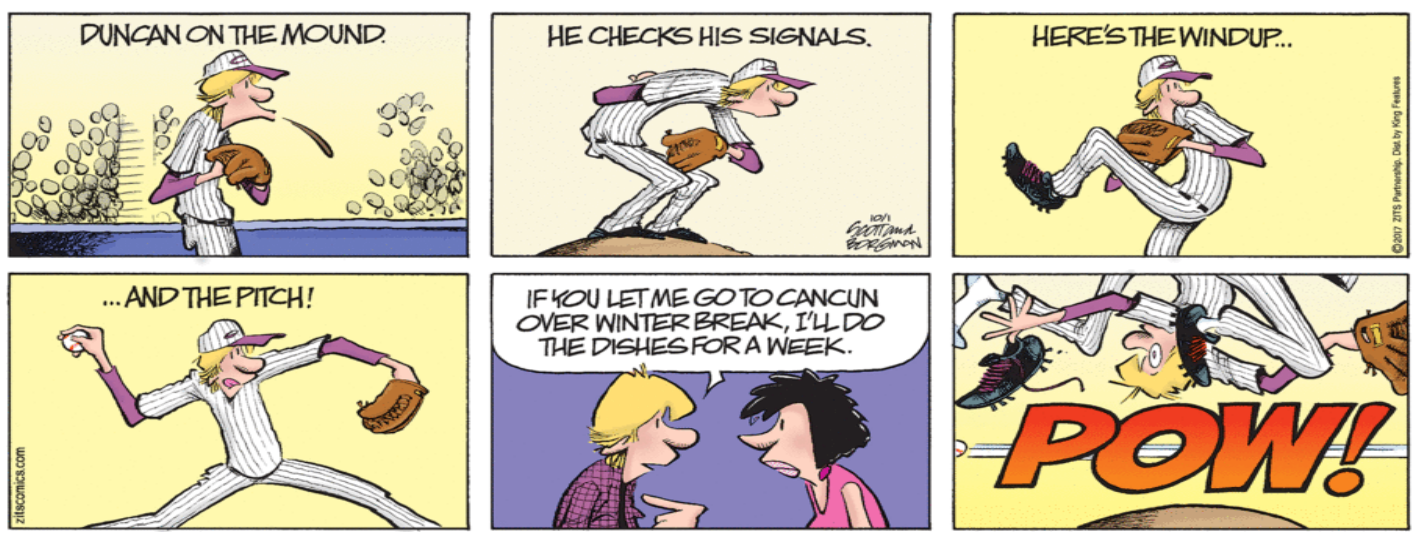

Source: http://zitscomics.com/

Picture 1. The Onomatopoeia in Comic Strips Example

POW! is onomatopoeia. In that comic strips, POW represented the sound of a blow or explosion. It could be seen clearly when the character in that strips luched.

\section{Onomatopoeia in Poem}

The use of Onomatopoeia in poem could be seen in Piqua (2014:18-19):

\section{The Noisy Me Donald's}

All the sounds in McDonald's are very loud.

Ah! Yell the kids in the Playplace.

some kids just say Whee!

Sizzle.... when you put French fries in the oil.

Pop Pop when the grease bubbles rise to the top.

Slap Slap another hamburger is cooked on the grill.

Bang Bang hurry to get the food on the trays.

Fizzle... when the pop is poured into the cup.

Bam Bam is the sound when the ice drops.

Slurp Slurp Cherry Coke is what I like.

Swish Swish The worker mops up the mess I made...

Ching Ching from the cash register.

Boom from the cashier slamming it shut.

squirt Squirt from the ketchup.

Screech from the cars in the drive thru. 


\section{Mmmmm...When the kids eat their Happy Meals. Yum! Yum! From the happy customers.}

There were 17 Onomatopoea in that poem:
Ah! : The sound of yelling.
Ouch! : The sound of shocking.
Whee! : The sound of enjoying something.
Sizzle : The sound of something put into hot oil.
Pop Pop : The sound of oil bubbling on the surface.
Slap Slap : The sound of something put into the grill.
Bang Bang : The sound of the tray touched the legs while running.
Fizzle : The sound of something poured into a cup.
Bam Bam : The sound of ice drops into a cup.
Slurp Slurp : The sound of drinking something with a loud sloppy sucking noise.
Swish Swish : The sound of rushing sound of the moving mop.
Ching Ching : The sound of an abrupt high-pitched ringing sound from cash-register.
Boom : The sound of the slamming shut of cash-register.
Squirt Squirt : The sound of the drop of ketchup liquid.
Screech : The sound of harsh cars.
Mmmmm : The sound of someone was enjoying eating something.
Yum! Yum! : The sound of happiness.

\section{Onomatopoeia in Another Language}

In Dofs' research (2008: 11-12), it was found that there were some examples of imitations of animals which were represented almost the same in English and in Swedish. At first there was the sound of a cat. The spelling was different, in English meow and in Swedish mjau, but the pronunciation was the same [miau]. Then there was the sound representing a cuckoo, [kuku:], which was also identical in the two languages even though the spelling was different slightly, cuckoo and ko-ko. Those were the only words which had the exact same pronunciation, but there were other words which were very similar. The sound a duck makes is represented by [kwakkwak] in English and it is very similar to the onomatopoeic word used to represent ducks in Swedish, [kvakkvak].

There are some words which are totally different. The sound representing a pig, [ $\eta \mathrm{k} \mathrm{\eta k}]$ and [nøf:nøf:], a horse, [nei] \& [gneg], and the sound representing a bee, [b $\Lambda \mathrm{z}] \&$ [sr:], do not have anything in common. [i:k] and [brø:l] represent the sound of a moose in English and Swedish; here, even though the vowels are quite close, the difference is obvious. The spelling of the three words, oink and nöff-nöff, neigh and gnägg, eek and bröl, is also completely different in the two languages. Finally buzz and surr have two features in common; the same 
vowel and double consonants at the end. However, the phonetic representations turn them into two different words.

\section{Comic}

Comic derived from the ancient Greek world komikos and associated with comedy. Comics are a graphic-art medium that often involves the design of pictures and words arranged in sequence to convey an idea, information or a narrative. They can sometimes be wordless, instead utilising symbolism and conventions, such as word ballons, to represent speech (Wigan, 2009:66).

\section{Comic Strips}

Comic strips, also known as "cartoon strips", are found daily in newspapers worldwide, and are usually a short series of cartoon illustrations in sequence. The creators of comic strips, comic books, and graphic novels are referred to as "cartoonists". Although humor is the most prevalent subject matter, adventure and drama are also represented in this medium (Toledo et al., 2014:22). Comic strips are basically a satirical look into the lives of the characters that inhabit them. The characters often reflects the subtle truths about people's own lives in their observations and insights into the world around them (Fairrington, 2009:8).

\section{Motivation}

Boardman et al (2008:27) said that motivation and engagement make reading enjoyable, increase strategy use during reading, and support comprehension. It is no surprise that those who enjoy reading, read more, or that reading more improves reading outcomes (as cited in Guthrie \& Wigfield, 2000). In their initial study, Gardner and Lambert (1959 as cited in Berns, 2010:168) classified students as integrative or instrumental in their orientation to studying foreign language such as French as a second language based on the reason they ranked as most applicable to themselves. However, through other research, it was shown that both of these motivation were related to each other.

The problem of motivating students is one that can be difficult in the context of second language learning if one accepts that such learning involves a construct such as integrativeness. In the socioeducational model (Gardner, 1985 as cited in Berns, 2010:169), integrativeness involves more than just an integrative orientation. It refers to the individual's cultural openness and interest in other communities and languages and favorable attitudes toward the target language group as well as an integrative orientation. Integrativenss is a higher-order construct with many levels. At one level, it can mean simply a willingness or capacity to take on characteristics of another cultural community. At another, it can reflect a full desire to identify and integrate with the other community. Most language learners do not 
study languages in order to become members of another cultural community (though some might), but at a minimum they must be able to make features (i.e., language) of another community part of their own behavioral repertoire, and there are individual differences in the ability (or willingness) to do this. To measure the interpretation scale of motivation, the researchers used this table:

Table 1. Score interpretation of motivation level

\begin{tabular}{ccc}
\hline $\begin{array}{c}\text { The Range of } \\
\text { Interpretation }\end{array}$ & Motivation Level & Range Score \\
\hline Very Agree & Highest & $45-50$ \\
\hline Agree & High & $35-44$ \\
\hline Average (Netral) & Middle & $25-34$ \\
\hline Disagree & Low & $15-24$ \\
\hline Very disagree & Lowest & $10-14$ \\
\hline
\end{tabular}

\section{Reading Comprehension}

Comprehension is not the only thing affected by speed. The faster people read, the more they have to concentrate. Speed reading without comprehension is called speed looking. To learn to speed read, readers need to separate comprehension from speed development. They can use visualization to help create their speed reading mind-set. The more background knowledge they have, the easier it is to read with speed and good comprehension. There are some ideas to create more background knowledge (Beale, 2008):

1. First, before reading, people should think about how much they already know about the topic.

2. Second, they should preview (cheat reading) their reading material to get some background knowledge before they jump in.

3. Third, they should ask questions and satisfy their inborn curiosity.

4. Next, they should listen more than they talk, so they can really hear what others are saying.

5. After that, they should travel to new places and experience a variety of transportation means such as bus, train, and airplane.

6. Then, they should engage in stimulating conversations with others,learn from them, build a broad vocabulary, regularly experience new things, read widely on topics they enjoy and dip into some areas they have not yet been exposed to. 
7. At last, they can get a copy of The Dictionary of Cultural Literacy and read a little everyday.

\section{METHODOLOGY}

This research used an experimental by using factorial design as a measurement for treatment effects. Factorial design examines the effects of multiple variables on a dependent variable (Mackey, 2010:158). The subject of the research was 40 students of third semester students of English Education Study Program of Faculty of Teacher Training and Education of University. The data were collected through Onomatopoeia test and Gardner's instrumental motivation questionnaire. The validity used content validity that measured the test really measured what it should be measured. The reliability of the test used Cronbach Alpha through SPSS 24. The result of Cronbach Alpha was .806. It meant the test was reliable and automatically valid. Meanwhile, since questionnaire of learning motivation was adopted from Gardner (1972) then it was reliable and no need to be tested anymore.

Table 2. The result of cronbach -alpha of reliability:

Reliability Statistics

\begin{tabular}{l|r}
$\begin{array}{l}\text { Cronbach's } \\
\text { Alpha }\end{array}$ & N of Items \\
\hline .806 & 40
\end{tabular}

The data were analyzed by using homogeneity and normality test, then independent t-test, and two-way ANOVA based on SPSS 24.

\section{RESULTS AND DISCUSSION}

It was shown that p-result .000 less than p-value $\alpha(.05)$. It meant null hypothesis was rejected and alternative one was accepted in both of classes (Onomatopoeia in Comic Strips strategy and in conventional one) which had high learning motivation. While in conventional class, students who had high instrumental motivation and the ones who had middle instrumental motivation got p-result result .000 less than p-value $\alpha(.05)$. It meant null hypothesis was rejected and alternative one was accepted. Next, it was shown that presult .000 less than p-value $\alpha(.05)$. It meant null hypothesis was rejected and alternative one was accepted in both of classes (Onomatopoeia in Comic Strips strategy and in conventional 
one) which had middle instrumental motivation. The same result also was shown in p-result .000 less than p-value $\alpha(.05)$ in Onomatopoeia in Comic Strips strategy class for students who had high instrumental motivation and in conventional one which had middle instrumental motivation. It meant null hypothesis was rejected and alternative one was accepted. In test of between subjects by using Two way ANOVA, null hypothesis was rejected and alternative one was accepted, In other words, there was a significant interaction between Onomatopoeia in Comic Strips and instrumental motivation (high and middle category) towards students' reading comprehension achievement $($ Sig. Value $=.011<.05)$.

\section{CONCLUSION}

The samples taken from both classes were homogeneous and normal. It could be seen in Levene Statistics p-value was .122. > $\alpha$ (.05). (homogeneous) while in Shapiro Wilk .193 (Onomatopoeia in Comic Strips strategy class) and .302 in conventional one strengthened by the result from normality test using Kolgomorov-Smirnov, the significant value of Onomatopoeia in Comic Strips strategy class) was .095 and .200 in conventional one $>\alpha(.05)$. Both of the data were classified as normal.

Most of all p-values shown through t-test were .000 whether in both of students who had high instrumental motivation in Onomatopoeia in Comic Strips strategy and in conventional one; whether in students who had high instrumental motivation in conventional one and the ones who had middle instrumental motivation in Onomatopoeia in Comic Strips strategy; whether in both of students who had middle instrumental motivation in Onomatopoeia in Comic Strips strategy and in conventional one; whether in students who had high instrumental motivation in Onomatopoeia in Comic Strips strategy and the ones who had middle instrumental motivation in conventional one, it meant that all p-values were lower than $\alpha(.05)$, so Onomatopoeia in Comic Strips strategy was effective if applied in certain group. Meanwhile in test of between subject, there was also a significant interaction between Onomatopoeia in Comic Strips and instrumental motivation ( in high and middle category) towards students' reading comprehension achievement $($ Sig. Value $=.011<.05)$.

\section{SUGGESTIONS}

In brief, Onomatopoeia in Comic Strips strategy is effective as one of strategy that can be applied in teaching Reading. Even, it is not effective only for Reading subject but also other subjects in English Education Study Program if there is a strong will to change common 
material system in academic. There is always a great way for creative educators and students if they believe.

\section{REFERENCES}

Abrams, M.H. and Geoffrey Galt Harpham. (2009). A glossary of literary terms. 9th ed. USA:Wasdworth Cengange Learning. Retrieved from: file:///C:/Users/admin/Downloads/literary\%20terms.pdf

Beale, Abby Marks and Pam Mullan. (2008). The complete idiot's guide to: Speed reading.new York: Alpha Books, penguin Group (USA), Inc. Retrieved from: https://docs.google.com/gview?url=http $\% 3 \mathrm{~A} \% 2 \mathrm{~F} \% 2 \mathrm{Fwww}$.pdfarchive.com\%2F2013 $\% 2 \mathrm{~F} 04 \% 2 \mathrm{~F} 26 \% 2 \mathrm{Fthe}-\mathrm{complete}$-idiot-s-guide-to-speed-reading $\% 2 \mathrm{Fthe}$-completeidiot-s-guide-to-speed-reading.pdf\&embedded=true.

Berns, Margie and Keith Brown. (2010). Concise encyclopedia of applied linguistics. UK: Elsevier Ltd. Retrieved from: http://bayanbox.ir/view/5699227883659621209/Applied-LinguisticsEncyc.pdf.

Boardman, A. G., Roberts, G., Vaughn, S., Wexler, J., Murray,C. S., \& Kosanovich, M. (2008). Effective instruction for adolescent struggling readers: A practice brief. Portsmouth,NH: RMC Research Corporation, Center on Instruction. Retrieved from: http://sld-education-fl.wikispaces.com/file/view/Practice+BriefStruggling+Readers.pdf.

Danesi, Marcel.(2009). Dictionary of media and communications. New York: M.E. Sharpe, Inc. $\quad$ Retrieved from: http://npu.edu.ua/!ebook/book/djvu/A/iif_kgpm_Dictionary_of_Media.pdf.

Dofs, Elin. (2008). Onomatopoeia and iconicity: A comparative study of English and Swedish animal sounds. Estetisk-Filosofiska Fakulteten. Sweden: Karlstads universitet Retrieved from: https://www.divaportal.org/smash/get/diva2:5727/FULLTEXT01.pdf.

Fairrington, Brian. (2009). Drawing cartoons \& comics for Dummies. Indianapolis: Wiley Publishing, Inc. Retrieved from: http://instantlion.com/wpcontent/uploads/2014/10/caricature.pdf.

Gardner R C (1985). Social psychology and second language learning: The role of attitudes and motivation. London: Edward Arnold Publishers in Berns, Margie and Keith Brown. (2010). Concise encyclopedia of applied linguistics. UK: Elsevier Ltd. Retrieved from: http://bayanbox.ir/view/5699227883659621209/AppliedLinguisticsEncyc.pdf.

Mackey, Alison and Susan M Gass . (2010). Second language research: Methodology and design, 10th ed. New Jersey, USA: Lawrence Erlbaum Associates, Inc. 
Piqua City School. (2014). Onomatopoeia poems and animal riddles. P.E.T.S: Yolanda the Yarnspinner Divergent \& Creative Thinking. Retrieved from: http://www.piqua.org/Downloads/YOLANDA_Book2013-2014.pdf.

Toledo, Michael A., Rosanelia A, Yangco., Allen A, Espinosa. (2014). Media Cartoons: Effects on issue resolution in environmental education. International Electronic Journal of Environmental Education, 4(1), 19-51. Retrieved from: http://files.eric.ed.gov/fulltext/EJ1060551.pdf.

Wigan, Mark. (2009). The visual dictionary of illustration. Switzerland: AVA Publishing SA. Retrieved from: file:///D:/the-visual-dictionary-of-ilustration.pdf. 